Volume 9 Nomor 1 Tahun 2021

\title{
Penggunaan Media Video Interaktif Untuk Meningkatkan Keterampilan Berbicara Bahasa Indonesia Peserta Didik Kelas 5 SDN Mrahu
}

\section{Puspita Intan Kusumaningrum}

Universitas Sebelas Maret

intanpuspita37992@gmail.com

\section{Article History}

received 30/4/2021

revised 30/5/2021

accepted 30/6/2021

\begin{abstract}
The purpose of this study is to describe the results of improving students' speaking skills using interactive video media for 5th grade students at SDN Mrahu, Kartoharjo District, Magetan Regency. This research is a classroom action research which was conducted for two cycles. Cycles I and II have two meetings each. Each meeting consists of four stages, namely planning, implementation, observation, and reflection. Data collection techniques in this study, namely: observation, interviews, and tests. The results obtained from the test data showed that in the pre-cycle there were $41 \%$ complete KKM. In cycle 1 there were $59 \%$ complete KKM so the cycle continued. Then in cycle 2 there were $88 \%$ complete KKM so the cycle was stopped. The data showed an increase from pre-cycle to cycle 2. And the success of the study was in accordance with the success indicators obtained during cycle 2, namely $88 \%$ of students completed the $K K M$. Thus, it can be concluded that the use of interactive video media can improve the speaking skills of 5th grade students at SDN Mrahu.
\end{abstract}

Keywords: Speaking Skills, Interactive Video Media, Indonesian Language

\begin{abstract}
Abstrak
Tujuan penelitian ini adalah Mendiskripsikan Hasil Peningkatan Keterampilan Berbicara Peserta Didik Dengan Menggunakan Media Video Interaktif Pada Peserta Didik Kelas 5 SDN Mrahu Kecamatan Kartoharjo Kabupaten Magetan. Penelitian ini adalah penelitian tindakan kelas yang dilakukan selama dua siklus. Siklus I dan II masing-masing dua pertemuan. Pada tiap pertemuan terdiri atas empat tahapan yaitu perencanaan, pelaksanaan, observasi, dan refleksi. Teknik pengumpulan data pada penelitian ini, yaitu: observasi, wawancara, dan tes. Hasil penelitian yang didapat dari data tes memperlihatkan bahwa pada prasiklus terdapat $41 \%$ tuntas KKM. Pada siklus 1 terdapat 59\% tuntas KKM sehingga siklus dilanjutkan. Kemudian pada siklus 2 terdapat $88 \%$ tuntas KKM sehingga siklus dihentikan. Data tersebut memperlihatkan terjadi peningkatan dari prasiklus sampai siklus 2. Dan keberhasilan penelitian sesuai dengan indikator keberhasilan didapat saat siklus 2, yaitu $88 \%$ peserta didik tuntas KKM. Dengan demikian dapat disimpulkan bahwa penggunaan media video interaktif dapat meningkatkan keterampilan berbicara peserta didik kelas 5 SDN Mrahu
\end{abstract}

Kata kunci: Keterampilan Berbicara, Media Video Interaktif, Bahasa Indonesia 


\section{PENDAHULUAN}

Kondisi pandemi Covid-19 ini mengakibatkan perubahan yang luar biasa, termasuk dalam bidang pendidikan. Seolah seluruh jenjang pendidikan 'dipaksa' bertransformasi untuk beradaptasi secara tiba-tiba drastis untuk melakukan pembelajaran dari rumah melalui media daring (online). Ini tentu bukanlah hal yang mudah, karena belum sepenuhnya siap. Problematika dunia pendidikan yaitu belum seragamnya proses pembelajaran, baik standar maupun kualitas capaian pembelajaran yang diinginkan. (KH. Lalu Gede Muhammad Zainuddin Atsani, 2020).

Belajar di rumah dengan menggunakan media daring mengharapkan orang tua sebagai role model dalam pendampingan belajar anak, dihadapi perubahan sikap. Masa pandemi Covid-19 ini bisa dikatakan sebagai sebuah peluang dalam dunia pendidikan, baik pemanfaatan teknologi seiring dengan industri 4.0, maupun orangtua sebagai mentor. Harapannya, pascapandemi Covid-19, kita menjadi terbiasa dengan sistem saat ini sebagai budaya pembelajaran dalam pendidikan. (KH. Lalu Gede Muhammad Zainuddin Atsani, 2020).

Berdasarkan pendapat Rita Eka Izzaty di atas, maka peserta didik Sekolah Dasar perlu dibekali dengan keterampilan berbahasa khususnya keterampilan berbicara agar nantinya peserta didik dapat menggunakan keterampilan tersebut untuk bersosialisasi di masyarakat. Guru memiliki peran penting dalam melatih keterampilan berbicara peserta didik melalui kegiatan pembelajaran Bahasa Indonesia. Hal tersebut sesuai dengan pendapat Sabarti Akhadiah, dkk. (1993: 10) dalam Riani Astuti (2015) yang mengemukakan bahwa tujuan pembelajaran Bahasa Indonesia di Sekolah Dasar yaitu, peserta didik dapat menggunakan bahasa dengan berbagai fungsinya dalam kegiatan berfikir, bernalar, berkomunikasi, dan berinteraksi.

Berdasarkan wawancara dengan guru kelas 5 SDN Mrahu Kecamatan Kartoharjo Kabupaten Magetan diketahui bahwa proses pembelajaran pada masa pandemi ini hanya lewat whatsapp group yang prosedurnya guru memberikan tugas peserta didik lebih banyak mengacu pada LKPD dan juga buku paket misalnya guru hanya memberikan tugas "Hari ini tugas kalian mengerjakan buku LKPD halaman 3 sampai 7" tanpa disertai pejelasan materi atau pengatar dari guru yang menyebabkan peserta didik kesulitan dalam mengerjakan tugas mereka. Masalah selanjutnya keterbatasan media pembelajaran dan sumber belajar yang digunakan guru dalam menyampaikan pembelajaran. Tidak adanya variasi media dalam pembelajaran menyebabkan guru hanya menugaskan peserta didik menjawab soal yang ada di buku sehingga menyebabkan rendahnya minat peserta didik dalam pembelajaran Bahasa Indonesia menjadi kendala dalam pembelajaran, proses belajar mengajar tidak berlangsung kondusif. Peserta didik nampak bosan dengan tugas yang diberikan guru dan memilih untuk bermain ketimbang belajar bahkan sebagian peserta didik tidak mengetahui tugas mereka karena HP yang dibawa orang tua bekerja sehingga peserta didik tersebut ketinggalan materi dan tugas.

Keterampilan peserta didik dapat di tingkatkan dengan memperbaiki proses belajar mengajar pada masa pandemi ini salah satunya dengan memakai media yang bersifat inovatif. Berdasarkan hasil wawancara diketahui bahwa salah satu permasalahan yang ada adalah tidak adanya variasi media dalam pembelajaran. Untuk itu maka salah satu upaya yang dapat dilakukan untuk meningkatkan keterampilan berbicara peserta didik adalah memberikan variasi dalam pembelajaran yaitu dengan video inovatif.

Media pembelajaran adalah sebuah alat yang berfungsi untuk menyampaikan pesan pembelajaran. Dengan adanya media pembelajaran dapat mempengaruhi iklim, kondisi, dan lingkungan belajar yang ditata dan diciptakan oleh guru. Bentuk-bentuk stimulus dapat dipergunakan sebagai media pembelajaran diantaranya adalah hubungan atau interaksi manusia, realita, gambar bergerak atau tidak, tulisan dan suara yang direkam. Computer Technology Research (CTR) menyampaikan bahwa 
orang hanya mampu mengingat $20 \%$ dari yang dilihat dan $30 \%$ dari yang didengar, tetapi orang dapat mengingat $50 \%$ dari yang dilihat dan didengar dan $80 \%$ dari yang dilihat, didengar dan dilakukan sekaligus. Daryanto (2016)

Menurut Daryanto (2016: 88) "media video adalah segala sesuatu yang memungkinka sinyal audio dapat dikombinasikan dengan gambar secara sekuensial." Video merupakan suatu medium yang sangat efektif untuk digunakan dalam membantu proses pembelajaran, baik untuk pembelajaran massal, individual, maupun secara berkelompok (Daryanto, 2016:86). Sedikit banyak video merupakan salah satu alternatif dalam mengatasi rendahnya hasil belajar, termasuk di dalamnya penguasaan konsep materi. Video dapat dimanfaatkan dalam pembelajaran karena dapat memberikan pengalaman tersendiri kepada peserta didik, selain itu juga dikarenakan kemampuan video cukup efektif untuk memvisualisasikan materi yang bersifat dinamis. Video pembelajaran interaktif digunakan dalam proses pembelajaran. Video ini, lebih berorientasi pada konten (isi) termasuk di dalamnya interaktivitas, grafis, sound dan berbagai teknik untuk membantu memahamkan ke peserta didik dengan cepat. Video pembelajaran interaktif berbasis materi dan soal merupakan alat bantu guru dalam proses pembelajaran di kelas dan tidak menggantikan guru secara keseluruhan.

Berdasarkan uraian di atas maka tujuan penelitian ini adalah : Mendiskripsikan Hasil Peningkatan Keterampilan Berbicara Peserta Didik Dengan Menggunakan Media Video Interaktif Pada Peserta Didik Kelas 5 SDN Mrahu Kecamatan Kartoharjo Kabupaten Magetan.

\section{METODE}

Penelitian ini adalah penelitian tindakan kelas menggunakan model Kemmis dan Mc. Taggart terdiri dari dua siklus dengan setiap siklusnya terdiri dari perencanaan (planning), pelaksanaan (action), pengamatan (observing), dan refleksi (reflection). Siklus I pertemuan pertama dilaksanakan pada hari senin tanggal 8 maret 2021 dan pertemuan kedua dilaksanakan hari rabu tanggal 10 maret 2021. Siklus II pertemuan pertama dilaksanakan pada hari senin tanggal 5 april 2021 dan pertemuan kedua hari rabu tanggal 7 april 2021. Subjek penelitian tindakan kelas ini adalah peserta didik kelas 5 SDN Mrahu Kecamatan Kartoharjo Kabupaten Magetan tahun pelajaran 2020/2021. Peserta didik yang menjadi subjek penelitian adalah peserta didik kelas 5 yang berjumlah 17 peserta didik terdiri dari 9 peserta didik laki-laki dan 8 peserta didik perempuan. Teknik pengumpulan data pada penelitian ini, yaitu: observasi, wawancara, dan tes. Validitas data menggunakan triangulasi sumber dan triangulasi teknik. Analisis data melalui reduksi data, penyajian data, dan penarikan kesimpulan.

\section{HASIL DAN PEMBAHASAN}

Siklus I pertemuan pertama dilaksanakan pada hari senin tanggal 8 maret 2021 dan pertemuan kedua dilaksanakan hari rabu tanggal 10 maret 2021. Pelaksanaan pembelajaran dilaksanakan secara daring menggunakan zoom meeting. Guru menyapa peserta didik dan memberikan link zoom meeting serta mengirim video interaktif yang dibuat guru serta LKPD untuk tugas hari ini. Lalu guru memberikan materi melalui zoom meeting dengan melakukan tatap muka secara virtual dengan para peserta didik serta melakukan sesi tanya jawab maupun diskusi dan menjelaskan bahwa peserta didik dapat melihat kembali materi yang mereka kurang kuasai atau tertinggal pada video interaktif yang sudah di share oleh guru di whatsapp group. Serta tetap mengingatkan peserta didik untuk mengerjakan dan mengirim tugas yang guru berikan secara tepat waktu.

Pada akhir Siklus I, peneliti dan guru kelas melakukan refleksi (perenungan) tentang keseluruhan proses Siklus I. Hasil refleksi Siklus I adalah sebagai berikut : (1) Pada siklus 1 pembelajaran berjalan agak mundur karena banyak peserta didik yang telat masuk zoom meeting karena mereka masih baru menggunakan pembelajaran 
daring. (2) Banyak peserta didik yang enggan mendownload materi bahan ajar yang diberikan guru melalui whatsapp group. (3) Peserta didik hanyak melihat video pembelajaran interaktif sekilas tanpa mencermati dengan teliti materi apa yang disampaikan di video interaktif tersebut sehingga kurang maksimal penggunaan media video interaktif bagi peserta didik. (4) Pada saat ditunjuk berbicara atau membaca ada peserta didik yang menghindar atau kurang bersemangat. (5) Ada peserta didik yang telat mengumpulkan tugas yang diberikan guru karena hp dibawa kerja orang tua.

Berdasarkan hasil refleksi pada Siklus I disusunlah rencana tindakan kelas untuk Siklus II. Hasil refleksi Siklus I dinyatakan belum berhasil, dan belum berhasilnya tindakan ini lebih disebabkan oleh adanya metode pembelajaran yang mungkin baru diterapkan dalam pembelajaran berbicara. Maka peneliti membuat perencanaan seperti berikut : (1) Kualitas pembelajaran berbicara dengan media video interaktif perlu ditingkatkan. Meneruskan tindakan Siklus pertama dengan menggunakan media video interaktif yang mungkin lebih diperjelas tulisan storyboard sehingga lebih terlihat oleh peserta didik. (2) Peningkatan sikap berbicara peserta didik agar lebih berani mengungkapkan ide -ide didepan teman-teman dan guru pada saat zoom meetting berlangsung. (3) Meningkatkan kemampuan berbicara dengan memperbanyak latihanlatihan dengan cara guru memberikan lebih banyak tugas yang melatih berbicara dibandingkan dengan menulis.

Berdasarkan hasil observasi dan crosschek terhadap guru, kemudian dilakukan refleksi. Adapun hasil refleksi pada Siklus II ini sebagai berikut: Kegiatan pembelajaran pada keterampilan dengan menggunakan media video interaktif dapat dikatakan berjalan cukup baik sesuai dengan harapan. Kenyataan ini terlihat dari aktifitas dan semangat peserta didik dalam pembelajaran sebelum menggunakan media pembelajaran dan sesudah menggunakan media pembelajaran. Tentu saja ada perbedaan yang sangat mencolok. Tugas dan tanggung jawab berusaha untuk dikerjakan dengan benar dan tepat waktu. Saling mengisi diantara teman sudah tampak, antusias semakin meningkat selama pembelajaran berlangsung. Peserta didik semakin mudah memahami apa yang dilihat pada video interaktif sehingga dapat meningkatkan daya imaginasi peserta didik dan kemampuan keterampilan berbicara peserta didik.

Pengelolaan kelas oleh guru cukup berlangsung semakin kondusif dan menyenangkan. Para peserta didik sudah dapat mengembangkan daya imaginasinya dan mampu meningkatkan kemampuan berbicara dengan inovasi teknik pembelajaran yang dilakukan guru. Guru semakin yakin bahwa media video interaktif benar-banar sangat bermanfaat dalam menyampaikan materi kepada peserta didik. Sisi lain peserta didik dapat belajar dengan mudah mengamati secara langsung, mengimaginasi, sehingga peserta didik dapat mengeluarkan ide-idenya, berikut dapat mengkomunikasikan secara lisan dengan lancar di depan teman-temannya. Apabila para guru dapat menerapkan teknik dan metode pembelajaran menggunakan media pembelajaran ini,dan peserta didik pun dapat menerima dan mengikuti dengan baik, maka tidak mustahil para peserta didik akan dapat memiliki kemampuan mengikuti pembelajaran yang hasilnya bisa diharapkan sesuai dengan kurikulum dan kompetensi yang telah ditetapkan.

Indikator keberhasilan yang diharapkan minimal 80\% peserta didik memperoleh nilai 70 atau lebih sebagai batas tuntas, sebab Kriteria Ketuntasan Minimal ( KKM ) untuk mata pelajaran Bahasa Indonesia kelas 5 SDN Mrahu Kecamatan Kartoharjo Kabupaten Magetan adalah 70. Berdasarkan hasil evaluasi diperoleh hasil sebagai berikut : 
Tabel 1. Hasil Nilai Keterampilan Berbicara Bahasa Indonesia

\begin{tabular}{lccc}
\hline & Prasiklus & Siklus I & Siklus II \\
\hline Jumlah peserta didik tuntas KKM & 7 & 10 & 15 \\
\hline \% Peserta Didik tuntas KKM & 41 & 59 & 88 \\
\hline Rata-Rata Nilai Peserta Didik & 68,14 & 72,75 & 78,33 \\
\hline
\end{tabular}

Untuk memberikan gambaran yang lebih jelas pencapaian hasil penelitian dapat dilihat melalui grafik berikut ini :

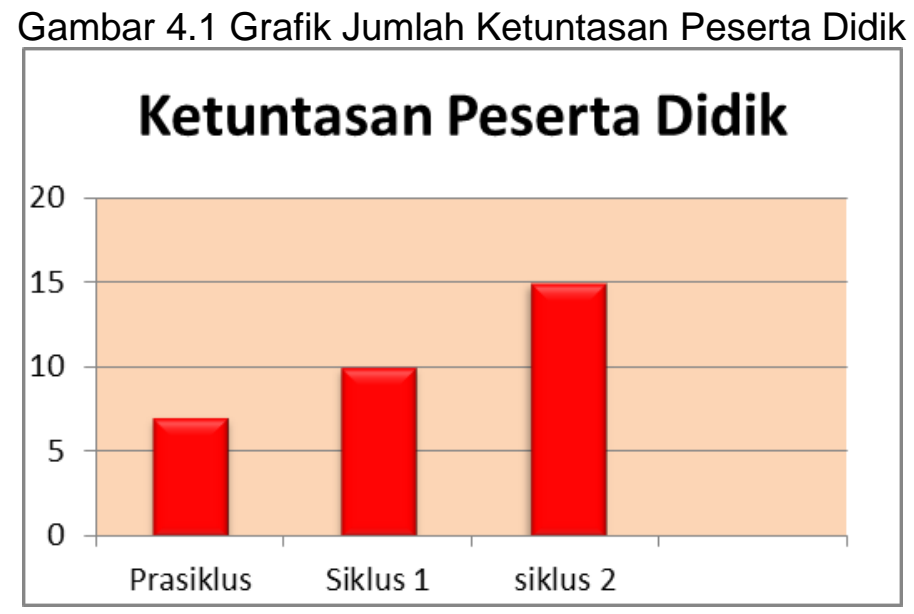

Peningkatan keterampilan berbicara tersebut secara bertahap dari Siklus I dan siklus II dapat dilihat melalui diagram berikut:

Gambar 4.24. Grafik Persentase Ketuntasan Peserta Didik

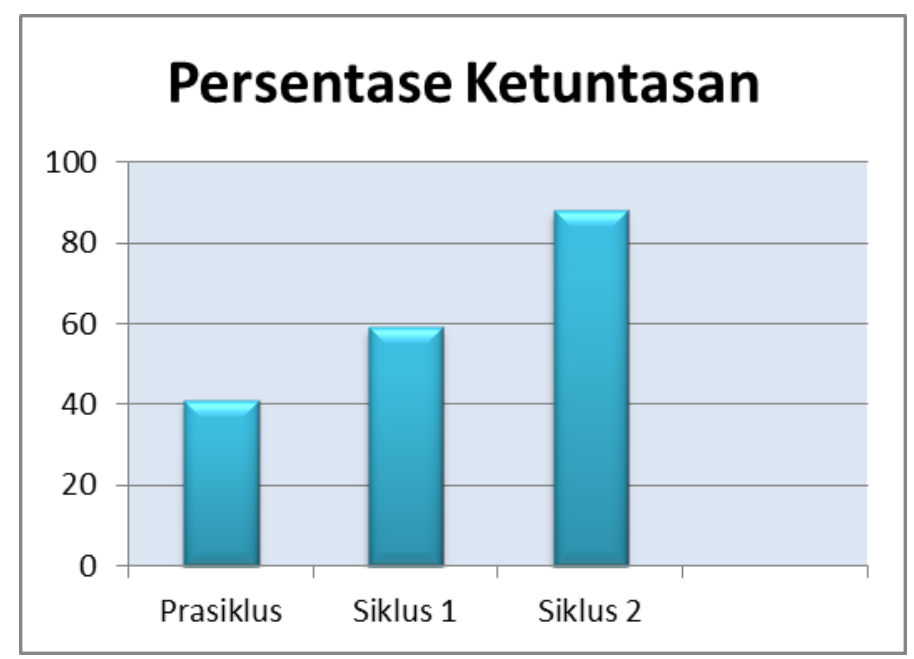

Sebagaimana telah diuraikan dalam awal tulisan ini masalah yang dihadapi dalam penelitian ini adalah keterampilan berbicara peserta didik masih sangat rendah. Kompetensi dasar dalam kurikulum mensyaratkan bahwa peserta didik diharapkan memiliki kemampuan minimal 70 dan tuntas klasikal minimal $80 \%$. Ternyata kemampuan ditetapkan dalam Kriteria Ketuntasan belum dapat diraih. Hal ini ditunjukkan oleh hasil uji coba sebelum tindakan dilaksanakan yakni jumlah peserta didik yang memiliki ketuntasan belajar berjumlah 7 peserta didik $(41 \%)$, dengan nilai rata-rata masih jauh dari KKM. Berdasarkan pada permasalahan tersebut peneliti melaksanakan penelitian tindakan kelas untuk meningkatkan kemampuan 
keterampilan berbicara peserta didik dengan menggunakan media gambar. Tujuannya agar peserta didik memiliki kemampuan mencapai batas KKM yang telah ditetapkan dalam Kriteria Ketuntasan yakni 70 dan daya serap mencapai $80 \%$.

Sebelum dilaksanakan metode penggunaan media video interaktif ini, para peserta didik sama sekali belum pernah melakukan pembelajaran dengan media gambar pada aspek berbicara. Pembelajaran yang pernah dilakukan hanya sebatas percakapan, membuat kalimat dengan kata yang sudah ditentukan. Dengan demikian peserta didik memang betul-betul belum mempunyai pengalaman tentang hal ini. Guru pun juga menyadari bahwa pembelajaran keterampilan berbicara belum berhasil.

Guru belum pernah menggunakan strategi khusus untuk menciptakan pembelajaran yang memperhatikan keterlibatan langsung bagi peserta didik. Pembelajaran yang dapat membangkitkan motivasi bagi peserta didik sehingga peserta didik memiliki kemampuan keterampilan sebagaimana yang diharapkan. Dengan kata lain pembelajaran aspek keterampilan berbicara belum berjalan baik dan maksimal. Setelah diterapkannya strategi dengan menggunakan media video interaktif beragam agar ada peningkatan dari siklus ke siklus berikutnya.

Peningkatan keterampilan berbicara tersebut adalah sebagai berikut : Pada Siklus I jumlah peserta didik mencapai KKM masih belum mencapai $80 \%$. Namun ada peningkatan dari uji coba awal 7 peserta didik (41\%) meningkat menjadi 10 peserta didik (59\%). Kenaikan baru mancapai 18\%, sedangkan nilai rata-rata 72,75 . Pencapaian yang belum maksimal sesuai dengan target Kriteria Ketuntasan tersebut faktor penyebabnya adalah penggunaan media video interaktif belum berjalan sebagaimana mestinya. Hal ini memang perlu dimaklumi dan disadari karena peserta didik dan guru belum terbiasa menjalani metode pembelajaran seperti itu. Penggunaan media video interaktif pada aspek keterampilan berbicara baru pertama kali dipraktikkan baik oleh peserta didik maupun guru.

Pada Siklus II pembelajaran keterampilan berbicara dengan media video interaktif diterapkan dengan melakukan perbaikan-perbaikan seperlunya guna mencapai tujuan yang diharapkan. Perbaikan dilakukan yakni dengan memberikan audio dan visual yang lebih menarik. Dengan inovasi audio visual tersebut dimaksudkan untuk memberikan motivasi dan antusias yang lebih baik dari sebelumnya. Hasilnya, setelah diadakan uji kompetensi Siklus II peserta didik yang mencapai batas tuntas bertambah menjadi 15 peserta didik (88\%), adapun nilai ratarata mencapai 78,33 artinya mengalami peningkatan sebesar $29 \%$ (5 peserta didik). Pada Siklus II ini pencapaian ketuntasan klasikal sebesar $88 \%$ dan kemampuan minimal 70 telah tercapai sehingga penelitian tindakan kelas telah dinyatakan selesai.

Dengan demikian dapat disimpulkan bahwa penggunaan media video interaktif dapat meningkatkan keterampilan berbicara peserta didik kelas 5 SDN Mrahu Kecamatana Kartoharjo Kabupaten Magetan pada tahun ajaran 2020/2021.

\section{SIMPULAN}

Indikator keberhasilan peningkatan keterampilan berbicara peserta didik pada penelitian ini dilihat $80 \%$ peserta didik tuntas KKM (dengan nilai 70 ). Hasil penelitian yang didapat dari data tes memperlihatkan bahwa pada prasiklus terdapat $41 \%$ ( 7 orang) peserta didik tuntas KKM. Pada siklus 1 terdapat 59\% (10 orang) peserta didik tuntas KKM sehingga siklus dilanjutkan. Kemudian pada siklus 2 terdapat 88\% (15 orang) peserta didik tuntas KKM sehingga siklus dihentikan. Data tersebut memperlihatkan terjadi peningkatan dari prasiklus sampai siklus 2. Dan keberhasilan penelitian sesuai dengan indikator keberhasilan didapat saat siklus 2, yaitu $88 \%$ peserta didik tuntas KKM. Nilai rata-rata unjuk kerja peserta didik di setiap siklus mengalami kenaikan. Pada prasiklus nilai rata-rata peserta didik adalah 68,14 atau di bawah KKM. Pada siklus 1 nilai rata-rata peserta didik adalah 72,75 sudah lebih dari KKM tetapi persentase ketuntasan belum terpenuhi. Pada siklus 2 nilai rata-rata 
peserta didik meningkat menjadi 78,33 atau di atas KKM dan persentase ketuntasan sudah terpenuhi.

\section{DAFTAR PUSTAKA}

Abdulhak, Ishak dan Deni Darmawan. 2015. Teknologi Pendidikan. Bandung: PT Remaja Rosdakarya.

Arsyad, Azhar. 2014. Media Pembelajaran. Jakarta : PT. Raja Grafindo Pustaka.

Daryanto. 2016. Media Pembelajaran Edisi ke-2 Revisi. Yogyakarta: Gava Media. 2011. Media Pembelajaran. Bandung: CV Yrama Widya.

Dra. Th. Sumini, M.Pd. Penelitian Tindakan Kelas Dan Pengembangan Profesi Guru. Yogyakarta : Universitas Sanata Dharma Yogyakarta, 2018

Inqidloatul Amaniyah. Peningkatan Keterampilan Berbicara Mata Pelajaran Bahasa Indonesia Materi Mendongeng Melalui Metode Bermain Peran Di Kelas III MI AsSyafiiyyah Pomahanjanggan Turi Lamongan. 2018. Surabaya : Universitas Islam Negeri Sunan Ampel Surabaya

KH. Lalu Gede Muhammad Zainuddin Atsani. 2020. Transformasi Media Pembelajaran Pada Masa Pandemi Covid-19. Lombok Timur : Al-Hikmah: Jurnal Studi Islam yang dikelola oleh LP2M IAIH NW

M. Edi Satriansyah. Penggunaan Media Interaktif Pada Pembelajaran Konsep Usaha Dan Energi Di Mtss Ulumul Quran Banda Aceh. 2016. Banda Aceh : Universitas Islam Negeri Ar - Raniry

Nanang Sofiyullah. Pengembangan Video Pembelajaran Interaktif Berbasis Materi Dan Soal Sebagai Suplemen Untuk Meningkatkan Penguasaan Konsep Mata Pelajaran IPA. 2015. Semarang : Universitas Negeri Semarang

Riani Astuti. Peningkatan Keterampilan Berbicara Menggunakan Media Pop Up Peserta didik Kelas III SD Negeri Gembongan Kecamatan Sentolo Kabupaten Kulon Progo Tahun Ajaran 2014/2015. Yogyakarta. Universitas Negeri Yogyakarta

Suharsimi Arikunto, Suhardjono, dan Supardi, Penelitian Tindakan Kelas. 2012. Jakarta: PT. Bumi Aksara

Suprihatiningrum, Jamil. 2016. Strategi Pembelajaran: Teori \& Aplikasi. Yogyakarta: Ar-Ruzz Media.

Tarigan, Henry Guntur. 2015. Berbicara Sebagai Suatu Keterampilan Berbahasa. Bandung: Angkasa. 